\title{
Simultaneous Removal of Iron and Hexavalent Chromium Via Slow Sand Filter Inoculated With Thiobacillus ferrooxidans and Waste management
}

Abrar Hussain Mian ( $\nabla$ abrar.microbio@hu.edu.pk)

Hazara University https://orcid.org/0000-0002-7337-5415

Research Article

Keywords:

Posted Date: April 12th, 2021

DOI: https://doi.org/10.21203/rs.3.rs-341874/v1

License: (1) (1) This work is licensed under a Creative Commons Attribution 4.0 International License.

Read Full License 


\section{Abstract}

Many places have common physical, biological, and chemical hazards and heavy metals contamination in drinking water is very important to study especially near industrial areas and mining sources. Application of microbes along with other physicochemical techniques can prove to be the suitable remediation technology for the removal of metals from water. This study aimed to remove iron and hexavalent chromium from water using slow sand filters inoculated with iron-oxidizing bacteria Acidothiobacillus ferrooxidans. An experiment was performed for 37 days under controlled conditions, a water sample was prepared synthetically and another sample was collected from water filtration plant from Abbottabad city in KP Province- Pakistan and influents and effluents were tested for different parameters like $\mathrm{pH}$, turbidity, hardness, total plate count, total dissolved solids, electrical conductivity and analysis of iron and hexavalent chromium in water. Acidothiobacillus ferrooxidans culture was isolated from soil using the differential iron media i.e. 9K medium and was inoculated into sand filters. At the end of the experiment, the removal efficiency of ferrous iron was about $52 \%$ and that of hexavalent chromium was $60.2 \%$. In simultaneous treatment, it was observed that removal efficiency of iron was about $68 \%$ while that of hexavalent chromium was about $93 \%$ suggesting that slow sand filters were more effective for the removal of hexavalent chromium than iron. Hence, the designed slow sand filters were able to reduce the concentration of hexavalent chromium more efficiently than ferrous iron. And it was observed that slow sand filters can effectively remove ferrous iron and hexavalent chromium from water if they are inoculated with respective bacteria.

Key,words,. Hexavalent Chromium, Iron Oxidizing, Sand Filters, Acidothiobacillus ferrooxidans, waste management.

\section{Introduction}

Availability of clean water for the community is a challenge for scientists and local authorities to provide low cost solution for safe drinking water production especially for developing countries (abrar et al., 2020). In some regions, groundwater is no safer enough to drink directly. Many places have common physical, biological and chemical hazards and heavy metals contamination in drinking water is very important to study especially near industrial areas and mining source. Public health department has some routine analysis of metals before supplying to the community but it is in limited areas only (Qayyum et al., 2020). These heavy metals store in the body of human beings e.g., in lipids and the gastrointestinal system and can provoke health effects like cancer (Chowdhury et al., 2016). Many heavy metals e.g. copper, iron, zinc, cadmium, lead, chromium, mercury, nickel, cobalt, silver, manganese etc. have been reported in drinking water (Chowdhury et al., 2016) especially in those areas where mining practice is ongoing. Contamination of heavy metals in drinking water has many origins like rusting of pipes and water tanks made up of metal, industrial effluents, discarding of wastes of industries (Gowd and Govil, 2008), paints, battery and leather processing plants. Heavy metals migrate from surface water to groundwater from these industries (Krishna et al., 2009). One of the most important metals on earth's surface is iron that can be present in water in both soluble form (ferrous iron) and complex form (ferric 
iron). The presence of iron in surface water may also have an industrial sources e.g. mining etc. (Chaturvedi and Dave, 2012). Iron is found not only in surface water but is also present in groundwater. Leaching from iron containing rocks is the main cause behind the contamination of iron in surface water (Tekerlekopoulou et al., 2013). The acceptable iron concentration for drinking-water is $0.3 \mathrm{mg} / \mathrm{L}$ (Khatri et al., 2016). At initial stages, concentration of iron above this permissible level in drinking-water cannot be dangerous for health. On the other hand, non-stop intake of iron contaminated water can cause the impairment of haematopoiesis and may results in hemochromatosis, which damages different organs (spleen, liver, brain) of the body, if left untreated (Khatri et al., 2017). Other health issues like eye disorders (e.g. retinitis, conjunctivitis and choroiditis), cancer and cardiac disorders are also faced because of elevated iron concentration in the water (Alimohammadi et al., 2017). Chromium is found in environment in ores. It exists in two stable oxidation states, trivalent (III) and hexavalent chromium (IV). $\mathrm{Cr}$ (III) is one of the important trace elements i.e. essential for the metabolism of amino acids, glucose and lipids. From studies it is evidenced that metabolites of $\mathrm{Cr}$ (III) somewhat oxidize to cancer causing $\mathrm{Cr}(\mathrm{VI})$ and $\mathrm{Cr}(\mathrm{V})$ (Headlam and Lay, 2016). $\mathrm{Cr}(\mathrm{VI})$ is one of the major chromium species i.e. involved in different processes of industries. The permissible limit for total chromium comprising $\mathrm{Cr}$ (III), $\mathrm{Cr}(\mathrm{VI})$ and other forms and hexavalent chromium are $2 \mathrm{mg} / \mathrm{L}$ and $0.05 \mathrm{mg} / \mathrm{L}$ respectively according to drinking water guidelines by World Health organization (Gupta and Rastogi, 2009). $\mathrm{Cr}$ (III) is less toxic and mobile, whereas $\mathrm{Cr}(\mathrm{VI})$ is easily soluble and more toxic than trivalent. So, hexavalent chromium should be reduced to trivalent chromium to reduce adverse effects in body cell structures at increased concentrations. Cellular metabolism of $\mathrm{Cr}(\mathrm{VI})$ causes DNA damage. DNA single-strand breaks occur because of the metabolism of $\mathrm{Cr}(\mathrm{VI})$ that may cause cancers of body organs like liver, lungs and kidney (Pradhan et al., 3 2017). That's why hexavalent chromium is considered as carcinogenic.

Slow sand filters (SSF) are being manipulated since 200 years as a water purifying system (Haig et al., 2011). Slow sand filters (SSFs) because of their simple design and operation are reliabe, flexible, and have relatively inexpensive installation and operation and are being successfully used for drinking water production from centuries (Calvo-Bado et al., 2003). It is dependent on the formation of microbial community on sand surface that consists of algae, bacteria, fungi, actinomycetes and protozoa etc. (Stewart-Wade, 2011). This layer is called as "Schmutzudecke layer" where pathogens and certain organic chemicals like pesticides are entrapped \& degraded by microbes (Paranychianakis et al., 2006). SSFs require low flow rates and become more effective when Schmutzudecke matures or adjusts according to the particular concentration of particular pathogenic microbes or chemical to be broken down (Lee and Oki, 2013). The metal removal by inoculated sand filter has evidence that concentration of different metals like nickel, cadmium, zinc, copper, lead, etc. can be decreased via slow sand filtration (Diels et al., 2003). Thiobacillus ferrooxidans is a gram negative, acidophilic, chemoautotrophic bacterium that can oxidize ferrous iron. In different studies it has been discussed that Thiobacillus ferrooxidans has an ability to reduce toxic form of chromium i.e. hexavalent chromium to non-toxic trivalent chromium (Donati et al., 2003). In two different studies, Thiobacillus was used to treat iron and chromium separately. In current study both metals were tested together to see the removal by 
Thiobacillus ferrooxidans inoculated sand filter. These filter were constructed on lab scale and effective removal of iron and chromium were analyzed through these sand filters.

\section{Methodology}

\subsection{Design of slow sand filter column}

Five different sand filters were prepared. Sand filter one was used as a control, second filter was for the treatment of iron, and third filter was for the treatment of chromium containing wastewater, fourth filter was used to treat the mixed synthetic wastewater containing both iron and $\mathrm{Cr}$ together at different concentrations. Last column was used only for iron and chromium mining wastewater.

\subsection{Specification}

Filter specification was as followed: Sand bed height $1 \mathrm{~m}$, diameter $4 \mathrm{~cm}$, pebbles at the bottom to retain sand 6inches, Sand particle size $0.2-0.6 \mathrm{~mm}$. Flow rate was adjusted with the help of peristaltic pump at $200 \mathrm{ml} / \mathrm{hr}$. Water inflow was from top of the column and outflow from the bottom. The sand filtration media was prepared by thoroughly rinsing the sand with water and emptying the supernatant several times to remove fine particulate matter. The washed sand was then air dried and autoclaved at $121^{\circ} \mathrm{C}$ for 15 minutes for sterilization then sterile sand was used to fill the column.

\subsection{Bacterial isolation and inoculation of the sand filter}

$10 \mathrm{~g}$ of sample was mixed in mineral salts medium (MSM) as described by (Dopson and Lindstrom, 1999). Mineral salt medium (MSM) served as an essential medium for each liquid growing medium. Composition of MSM was (for $1 \mathrm{~L}$ distilled water): $\mathrm{KH}_{2} \mathrm{PO}_{4}(1 \mathrm{gm}) \mathrm{K}_{2} \mathrm{HPO}_{4}(1 \mathrm{gm}),\left(\mathrm{NH}_{4}\right)_{2} \mathrm{SO}_{4}(1 \mathrm{gm}), \mathrm{NaCl}$ (15gm), $\mathrm{MgSO}_{4}(0.2 \mathrm{gm}), \mathrm{CaCl}_{2}(0.017 \mathrm{gm}), \mathrm{FeCl}_{2}(1 \mathrm{gm})$. All the ingredients were dissolved in $1000 \mathrm{ml}$ distilled water, sterilized at $121^{\circ} \mathrm{C}$ for 20 minutes. $10 \mathrm{gm}$ of soil sample was added in $250 \mathrm{ml}$ of flask in triplicate and were kept in shaking incubator for 3 days at $30^{\circ} \mathrm{C}$. After 3 days $10 \mathrm{ml}$ of old MSM media was added in $250 \mathrm{ml}$ of new MSM media and incubated for 48 hours and then transferred to liquid $9 \mathrm{~K}$ medium. In MSM media $1 \mathrm{gm}$ of $\mathrm{FeCl}_{3}$ was added as a substrate. Silverman and Lundgren $9 \mathrm{~K}$ broth was used for the isolation of Thiobacillus ferrooxindans containing: $\left(\mathrm{NH}_{4}\right)_{2} \mathrm{SO}_{4}(3.0 \mathrm{~g} / \mathrm{L}), \mathrm{KCl}(0.1 \mathrm{~g} / \mathrm{L}), \mathrm{K}_{2} \mathrm{HPO}_{4}$ $(0.5 \mathrm{~g} / \mathrm{L}), \mathrm{MgSO}_{4} .7 \mathrm{H}_{2} \mathrm{O}(0.5 \mathrm{~g} / \mathrm{L}), \mathrm{Ca}\left(\mathrm{NO}_{3}\right)_{2}(0.01 \mathrm{~g} / \mathrm{L}), \mathrm{FeSO}_{4} .7 \mathrm{H}_{2} \mathrm{O}(44.3 \mathrm{~g} / \mathrm{L})$ (Silverman and Lundgren, 1959). The $\mathrm{pH}$ of the medium was adjusted by using $10 \mathrm{NH}_{2} \mathrm{SO}_{4}$ and $10 \mathrm{~N} \mathrm{NaOH}$. The media was sterilized and then placed in incubator for about 24 hours to check contamination (Tehreem et al., 2020). Enrichment of microorganisms was carried out with the $100 \mathrm{ml}$ liquid $9 \mathrm{k}$ medium in $250 \mathrm{ml}$ Erlenmeyer flasks at $300^{\circ} \mathrm{C}$ in a shaking incubator at $180 \mathrm{rpm}$ for almost 1 week. For purification, solid $9 \mathrm{~K}$ medium with $1.5 \%$ agar was used. The plates were incubated at $30^{\circ} \mathrm{C}$ for about 1 week. By repeating the above plating method, isolated bacteria were obtained. After purification, Thiobacillus ferrooxidans culture was added to the surface of sand filter.

Before addition of iron and chromium into the treatment filters, control was run. Distilled water was used as a control to initiate the experiment and treatment filter was not inoculated. After running control for 2 
weeks, filters were inoculated with the isolated bacterial strains, after which synthetically prepared iron and chromium wastewaters were added into their respective treatment filters. The bacterial count added to the filters was kept changing throughout the experiment. The calculated hydraulic retention time (HRT, time taken by the influent to remain inside the reactor) was 2 days. The influent flowing into the iron treatment filter (ITF) was containing $200 \mathrm{mg} / \mathrm{L}$ ferrous iron while the influent flowing into chromium treatment filter (CTF) containing $500 \mathrm{mg} / \mathrm{L}$ of hexavalent chromium ( $\mathrm{Cr} 6+)$. The effluent passing through the filters were collected on daily basis. Flow rate was adjusted at $200 \mathrm{ml} / \mathrm{hr}$ with the help of peristaltic pump.

\subsection{Cell Count by Neubauer Counting Chamber under microscope}

Water sample was observed under microscope using Neubauer chamber. Bacterial count in the media was measured by using microscope. While using neubauer counting chamber, coverslip was placed on upper area or on blocks of chamber for keeping sample smooth. $0.1 \mathrm{ml}$ Sample was poured with the help of dropper which is very minute amount. Counting chamber was observed under the microscope with $40 \mathrm{X}$ magnification. The vibrating or moving bacterial cell were counted inside chamber blocks. Bacterial cell was counted in per $\mathrm{ml}$ of the media. For the average cell count five different fields were randomly selected and observed (Strober, 2001). Numbers of cells was estimated by using formula: Total cells $\times 2.5 \times 105 \times$ dilution factor $=$ cells $/ \mathrm{ml}$ is shown in the Table 1 .

Table 1

Bacterial count added to filters every 4th day

\begin{tabular}{|ll|}
\hline Days & Bacterial count $(\mathrm{CFU} / \mathrm{mL})$ \\
\hline 1 & $2.4 \cdot 10^{5}$ \\
\hline 5 & $2.6 \cdot 10^{5}$ \\
\hline 13 & $3.1 \cdot 10^{5}$ \\
17 & $1.6 \cdot 10^{7}$ \\
\hline 21 & $3.5 \cdot 10^{7}$ \\
\hline 25 & $5 \cdot 10^{9}$ \\
\hline 29 & $5.5 \cdot 10^{9}$ \\
\hline 33 & $5.7 \cdot 10^{9}$ \\
\hline
\end{tabular}

2.5 Preparation of Ferrous ammonium sulphate $\left(\mathrm{FeSO}_{4} \cdot\left(\mathrm{NH}_{4}\right)_{2} \mathrm{SO}_{4} \cdot 6 \mathrm{H}_{2} \mathrm{O}\right)$ 
Ferrous ammonium sulphate was prepared by dissolving hydrated ferrous sulphate, $\mathrm{FeSO}_{4} \cdot 6 \mathrm{H}_{2} \mathrm{O}$ (7grams) and Ammonium sulphate, $\left(\mathrm{NH}_{4}\right)_{2} \mathrm{SO}_{4}$ (3.5grams) in water containing little quantity of Sulphuric acid, $\mathrm{H}_{2} \mathrm{SO}_{4}$, and passed resulted solution to crystallization where pale green crystals of ferrous ammonium sulphate, $\left(\mathrm{FeSO}_{4}\right.$. $\left.\left(\mathrm{NH}_{4}\right)_{2} \mathrm{SO}_{4} \cdot 6 \mathrm{H}_{2} \mathrm{O}\right)$, separated out.

\subsection{Sample preparation and collection}

Two types of samples were run through slow sand filter (SSF). Type 1 sample having different concentrations of iron and chromium separately were prepared in the laboratory and then mixed. Second type of sample was collected from mining wastewater discharge. A stock solution of iron, Fe was prepared by adding $20 \mathrm{ml}$ of conc. $\mathrm{H}_{2} \mathrm{SO}_{4}$ to $50 \mathrm{ml}$ water and dissolving $1.404 \mathrm{~g}$ of ferrous ammonium sulphate in it. Then $0.1 \mathrm{M} \mathrm{KMnO}_{4}$ was added dropwise until a faint pink colour appeared and then solution was diluted to $1000 \mathrm{ml}$ with water and mixed. $1 \mathrm{ml}$ of this solution containing $200 \mathrm{mg} / \mathrm{L} \mathrm{Fe} .2 .5 \mathrm{ml}$ of the solution was measured exactly and added to the water to make $1000 \mathrm{ml}$ of the solution. $1 \mathrm{ml}$ of this solution contained $0.5 \mathrm{mg} / \mathrm{L}$ of iron. Similarly, the stock standard solution of $\mathrm{Cr}$ was prepared by dissolving $1.4 \mathrm{~g}$ of potassium dichromate, $\mathrm{K}_{2} \mathrm{Cr}_{2} \mathrm{O}_{7}$, in $1000 \mathrm{ml}$ water. $1 \mathrm{ml}$ of this solution containing $50 \mu \mathrm{g} / \mathrm{L}$ of $\mathrm{Cr}$.

\subsection{Spectrophotometric analysis}

\subsubsection{Iron analysis via 1, 10-phenanthroline method}

The absorbance measurements were made with UV-Visible spectrophotometer (Federation and Association, 2005). Different reagents were used in this method like; Hydrochloric acid, $\mathrm{HCl}$ (containing less than $0.5 \mathrm{ppm}$ iron), Hydroxylamine solution: Prepared by dissolving $10 \mathrm{~g}$ of hydroxylamine hydrogen chloride $\left(\mathrm{NH}_{2} \mathrm{OH} . \mathrm{HCl}\right)$ in $100 \mathrm{ml}$ water, Ammonium acetate buffer: Prepared by dissolving $250 \mathrm{~g}$ of Ammonium acetate $\left(\mathrm{NH}_{4} \mathrm{C}_{2} \mathrm{H}_{3} \mathrm{O}_{2}\right)$ in $150 \mathrm{ml}$ water and $700 \mathrm{ml}$ conc. (glacial) acetic acid was added to it,

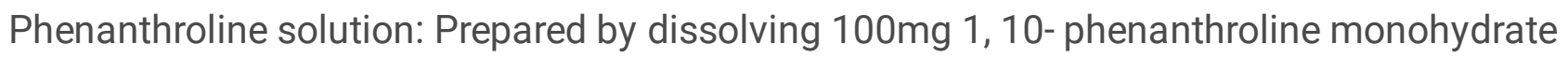
$\left(\mathrm{C}_{12} \mathrm{H}_{8} \mathrm{~N}_{2} \cdot \mathrm{H}_{2} \mathrm{O}\right)$ in $100 \mathrm{ml}$ water containing 2 drops of $\mathrm{HCl}$. Potassium permanganate, 0.1M: Prepared by dissolving 0.316 Potassium permanganate $\left(\mathrm{KMnO}_{4}\right)$ in $100 \mathrm{ml}$ distilled water, Stock iron solution: Prepared by dissolving $1.404 \mathrm{~g}$ ferrous ammonium sulphate $\left(\mathrm{FeSO}_{4} \cdot\left(\mathrm{NH}_{4}\right)_{2} \mathrm{SO}_{4} \cdot 6 \mathrm{H}_{2} \mathrm{O}\right)$ in $50 \mathrm{ml}$ water in which $20 \mathrm{ml}$ conc. $\mathrm{H}_{2} \mathrm{SO}_{4}$ was also added. $0.1 \mathrm{M} \mathrm{KMnO}_{4}$ was added dropwise till the persistence of faint pink color. Then the solution was diluted to $1000 \mathrm{ml}$ with water and mixed. $1 \mathrm{ml}$ of this solution contaiing $200 \mathrm{mg} / \mathrm{L}$ iron.

\subsection{Standard iron solution}

Standard iron solution was prepared daily for use. $2.5 \mathrm{ml}$ stock solution was pipetted into $1000 \mathrm{ml}$ volumetric flask and was diluted to mark with distilled water. $1 \mathrm{ml}$ of this solution containing $0.5 \mathrm{mg} / \mathrm{L}$ iron.

For analysis of total iron, sample was mixed thoroughly and $50 \mathrm{ml}$ was measured into a $200 \mathrm{ml}$ conical

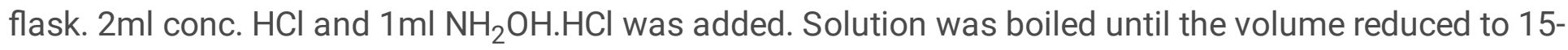


$20 \mathrm{ml}$ and was cooled and then transferred to $100 \mathrm{ml}$ volumetric flask. Then $10 \mathrm{ml}$ ammonium acetate and $4 \mathrm{ml}$ phenanthroline solution was added and diluted to mark with water, mixed thoroughly and allowed for about 10 minutes for maximum color development. The absorbance was checked at $510 \mathrm{~nm}$.

For ferrous iron, $100 \mathrm{ml}$ sample was acidified with $2 \mathrm{ml} \mathrm{HCl}$. $50 \mathrm{ml}$ from this acidified sample was separated to which $20 \mathrm{ml}$ phenanthroline solution and $10 \mathrm{ml}$ ammonium acetate solution was added with vigorous stirring and diluted to $100 \mathrm{ml}$ and color intensity was measured within 5-10 minutes at the wavelength of $510 \mathrm{~nm}$. Ferric iron was calculated by subtracting ferrous iron from total iron.

The concentration of total iron and ferrous iron was calculated by using the formula below:

$\mathrm{Y}=\mathrm{mx}+\mathrm{b}(\mathrm{Y}=$ absorbance, $\mathrm{m}=$ slope, $\mathrm{x}=$ concentration, $\mathrm{b}=\mathrm{Y}$-intercept $)$

\subsubsection{Chromium analysis via 1, 5- diphenylcarbazide method}

The absorbance measurements were made with UV-Visible spectrophotometer having specification, at the wavelength of $540 \mathrm{~nm}$ (Federation and Association, 2005). Different reagents used for this purpose were; Stock chromium solution; Prepared by dissolving $141.4 \mathrm{mg}$ potassium dichromate, $\mathrm{K}_{2} \mathrm{Cr}_{2} \mathrm{O}_{7}$ in $1000 \mathrm{ml}$ distilled water. $1 \mathrm{ml}$ of this solution containing $50 \mu \mathrm{g} \mathrm{Cr}$.

\subsection{Standard Chromium solution;}

$10 \mathrm{ml}$ of stock chromium solution was diluted to $100 \mathrm{ml}$ with distilled water. $1 \mathrm{ml}$ of this solution containing $5 \mu \mathrm{g} \mathrm{Cr}$. $18 \mathrm{~N}$ Conc. Nitric acid $\left(\mathrm{HNO}_{3}\right)$ and $6 \mathrm{~N}$ Sulphuric acid, conc., Sulphuric acid, $0.2 \mathrm{~N}$; Prepared by diluting the $17 \mathrm{ml} 6 \mathrm{~N} \mathrm{H}_{2} \mathrm{SO}_{4}$ to $500 \mathrm{ml}$ with distilled water, Phosphoric acid, $\mathrm{H}_{3} \mathrm{PO}_{4}$, conc,Diphenylcarbazide solution; Prepared by dissolving the $250 \mathrm{mg} \mathrm{1,5-diphenylcarbazide} \mathrm{in}$ $50 \mathrm{ml}$ acetone. $\mathrm{NaOH}(1 \mathrm{~N})$; Prepared by dissolving $4 \mathrm{~g}$ of $\mathrm{NaOH}$ in $1 \mathrm{~L}$ distilled water.

\subsection{Color development and measurement:}

$0.25 \mathrm{ml} / 5$ drops phosphoric acid, $\mathrm{H}_{3} \mathrm{PO}_{4}$, were added to $95 \mathrm{ml}$ water sample, $0.2 \mathrm{~N}$ sulphuric acid and $\mathrm{pH}$ meter was used to adjust the $\mathrm{pH} 2 \pm 0.5$. Solution was transferred to $100 \mathrm{ml}$ volumetric flask and diluted to $100 \mathrm{ml}$ and mixed. $2 \mathrm{ml}$ diphenylcarbazide solution was added and left for 5-10 minutes for full color development. An appropriate portion was transferred to $1 \mathrm{~cm}$ absorption cell and absorbance was measured 540nm using distilled water as a reference/ blank.

Calculation $\mathrm{Y}=\mathrm{mx}+\mathrm{b}(\mathrm{Y}=$ absorbance, $\mathrm{m}=$ slope, $\mathrm{x}=$ concentration, $\mathrm{b}=\mathrm{Y}$-intercept $)$.

Removal efficiency of ferrous iron and hexavalent chromium was calculated by the following formula: 100. Percentage removal $(\%)=\mathrm{Co}-\mathrm{Ce} / \mathrm{Co}\left(\right.$ Where $\mathrm{Co}=$ initial concentration of $\mathrm{Fe}^{2+} \mathrm{or} \mathrm{Cr}^{6+}, \mathrm{Ce}=$ final concentration of $\mathrm{Fe}^{2+}$ or $\mathrm{Cr}^{6+}$ ).

\subsection{Physio-chemical characteristics}


The multi-parameter meter, Model 520, was used for the measurement of $\mathrm{pH}$, temperature, EC and TDS. The meter was standardized before use for measuring parameters. The probe of multi-meter was washed with distilled water before taking readings of effluents and influents and after use. For measurement of hardness of collected sample EDTA solution and Erichrome black T solution was prepared. EDTA solution was used as a titrant while erichrome black $T$ was used as indicator. The hardness was calculated via following formula:

1000 $\cdot$ Hardness $(\mathrm{mg} / \mathrm{L})=$ EDTA used $/$ volume of sample.

The turbidity of water samples, influents and effluents were measured with the help of turbidity meter. The meter was calibrated or standardized before used and washed with distilled water after use (APHA, 2005).

Total plate count (TPC) Total plate count (TPC) in the effluent and influent collected from water filtration plant, Abbottabad was checked (Qayyum et al., 2020).. For this purpose nutrient agar was prepared by dissolving 28 grams of nutrient agar in $1000 \mathrm{ml}$ distilled water and autoclaved at $121^{\circ} \mathrm{C}$ for 15 minutes. 1 $\mathrm{ml}$ of water sample was used as aliquot and spread on nutrient agar with the help of spreader in sterilized conditions and incubated for 24 hours. After 24 hours of incubation at $37^{\circ} \mathrm{C}$, colony forming units were counted with colony counter.

\section{Results And Discussion}

\subsection{Slow sand filter 1. Control}

First slow sand filter setup was control setup that was run at room temperature i.e. $25 \pm 5$. In this setup distilled water was used as an influent that passed through slow sand filter. This setup was run without the bacterial inoculation and $\mathrm{pH}$ of the distilled water used was 6.6. This setup was run for about 14 days ( 2 weeks) and it was observed that effluent collected after filtration contained iron in a concentration of about $9.7 \mathrm{mg} / \mathrm{L}$ while there was no concentration of hexavalent chromium in the effluent Fig. 2

\subsection{Slow sand filter 2 (Iron treatment)}

During start of experiment the bacterial count was $2.4 \mathrm{CFU} / \mathrm{mL}$. As initial concentration of ferrous iron was $200 \mathrm{mg} / \mathrm{L}$ at first day of the experiment it was observed that the concentration of ferrous iron $\left(\mathrm{Fe}^{2+}\right)$ in the effluent was same as that of the initial concentration and there was no decrease in iron concentration in the effluent. As the treatment filters were operated at room temperature, throughout the $25 \pm 5^{\circ} \mathrm{C}$. At this time the $\mathrm{pH}$ was 2 , as the treatment continued it was observed that till 6 th day there was slow and gradual decrease in the ferrous iron concentration. At 7th day there was a sudden decrease in the $\mathrm{Fe}^{2+}$ concentration and it was decreased from $200 \mathrm{mg} / \mathrm{L}$ to $161 \mathrm{mg} / \mathrm{L}$. After that there was slow and stable decrease in concentration and at day 29 the concentration of $\mathrm{Fe}^{2+}$ measured was $106 \mathrm{mg} / \mathrm{L}$ and the iron removal efficiency at this point was $46.5 \%$. On last day which was 37 th day, the maximum decrease in iron concentration was $95 \mathrm{mg} / \mathrm{L}$ where the bacterial count was $5.7 \cdot 10^{9}$. It was observed that the removal efficiency was maximum i.e. $52 \%$. The mechanism of slow sand filtration involve physical as 
well as biological activity. A researcher Nsengiyumva in his study suggested mechanical straining, sedimentation, adsorption and chemical and biological activity are the most well known processes of slow sand filtration (Nsengiyumva, 1997). One of the reason behind decrease in concentration can be the pores between the grain of sand that trap the ions resulting in the decrease in concentration as suggested in a study that sandbed i.e. made up of $0.15 \mathrm{~mm}$ grains will possess pores of about $20 \mu \mathrm{m}$ diameter (Paramasivam et al., 1981). A study conducted on removal of iron and manganese from natural groundwater by continuous reactor using activated and natural mordenite mineral adsorption revealed that the iron removal was much better than manganese removal. The maximum value of iron removal efficiency from natural mordenite was $2.79 \%$ /minute (Zevi et al., 2018) while in this study the value of iron removal efficiency was about $52 \%$ at last day of experiment which was recorded as the maximum value shown in Fig. 3.

\subsection{Removal efficiency of ferrous $\left(\mathrm{Fe}^{2+}\right)$ iron}

Throughout the experimentation, it was observed that initially the removal efficiency of ferrous iron was very low till 4th day that was less than $1 \%$. On 5 th day, removal efficiency of ferrous iron increased to about $5 \%$. After 1 week of continuous process, the removal efficiency was increased to about $19 \%$. Slow sand filters were operated continuously and slow and stable increase in the removal efficiency was observed till 27 th day of experimentation. On 27 th day, the removal efficiency was about $39 \%$ and day 28 th, it was increased to about $46 \%$ showing $46 \%$ ferrous iron was removed till 27 th day. After that, from day 30 to 37 removal efficiency became stable and there was no increase in removal efficiency. On last day i.e. 37 th day, removal efficiency was maximum i.e. about $52 \%$ means about half of the ferrous iron was removed till last day of experiment. A research project entitled "removal of iron from ground water by sulphide precipitation" suggested that $83 \%$ removal of iron from ground water, having initial concentration of $1 \mathrm{mg} / \mathrm{L}$, was made possible by purifying samples of groundwater by hydrogen sulphide (H2S) under anaerobic conditions. It was observed that removal efficiency decreased to $80 \%$ and $75 \%$ with the increase in concentration of iron from $1 \mathrm{mg} / \mathrm{L}$ to $3.55 \mathrm{mg} / \mathrm{L}$ and $5.01 \mathrm{mg} / \mathrm{L}$ respectively and the levels were higher than World health organization (WHO) standards for drinking water although the contact time was more than the former test (Jusoh et al., 2011). In this research the slow and stable increase in the removal efficiency in the concentration of ferrous iron was observed without changing the initial concentration and a point reached where there was not as much increase in the removal efficiency was observed in Fig. 4 that was in the last working days.

\subsection{Slow sand filter 3 (Hexavalent Chromium treatment}

At the start of experiment bacterial count added was $2.4 \mathrm{CFU} / \mathrm{mL}$. As the initial concentration of hexavalent chromium $\left(\mathrm{Cr}^{6+}\right)$ was $500 \mathrm{mg} / \mathrm{L}$, on first day of experiment it was observed that the concentration of hexavalent chromium $\left(\mathrm{Cr}^{6+}\right)$ in the effluent was same as that of the initial concentration and there was no decrease in chromium concentration in the effluent. As the treatment filters were operated at room temperature, throughout the experimentation the temperature was $25 \pm 5^{\circ} \mathrm{C}$. At this time the $\mathrm{pH}$ was $4-5$, as the treatment continued it was observed that till 4 th day there was slow and gradual decrease in the $\mathrm{Cr}^{6+}$. On 5th and 6th day there was a sudden decrease in the $\mathrm{Cr}^{6+}$ concentration and it 
was reduced from $500 \mathrm{mg} / \mathrm{L}$ to $364 \mathrm{mg} / \mathrm{L}$ and $268 \mathrm{mg} / \mathrm{L}$ respectively. After that there was slow and stable decrease in concentration and on day 30th the concentration of $\mathrm{Cr}^{6+}$ measured were $202 \mathrm{mg} / \mathrm{L}$ and the $\mathrm{Cr}^{6+}$ removal efficiency at this point was $59.6 \%$. On last day which was 37 th day, the maximum decrease in the $\mathrm{Cr}^{6+}$ concentration was $198.6 \mathrm{mg} / \mathrm{L}$ where the bacterial count was $5.7 \mathrm{X} 10^{9}$. It was observed that the removal efficiency on last day was maximum i.e. $60.2 \%$. In another study, the researchers used a novel process for the removal of iron from ground water in which they used limestone packed column to increase efficiency of oxidation of ferrous iron $\left(\mathrm{Fe}^{2+}\right)$ and conduct alkylation and aeration at the same time. While observing the effect of hydraulic retention time (HRT) on the removal of iron, it was observed that by increasing the flow rate of water, the iron removal yield decreased as the contact time between the column and iron decreased (Sim et al., 2001). As shown in the Fig. 5 HRT was calculated as about 48 hours and flow rate was adjusted at $200 \mathrm{ml} /$ hour in order to increase the contact time between the sample and sand granules 33 and added biofilm and to increase the removal efficiency of ferrous iron from synthetic wastewater.

\subsection{Removal efficiency of hexavalent chromium $\left(\mathrm{Cr}^{6+}\right)$}

Initially it was observed that removal efficiency of hexavalent chromium $\left(\mathrm{Cr}^{6+}\right)$ was very low till 3rd day that was about $1 \%$. On 4 th day, a slight increase in removal efficiency was seen i.e. about $4 \%$ and on 5 th day, removal efficiency for $\mathrm{Cr}^{6+}$ suddenly increased to about $27 \%$. After 1 week of continuous process, at 7 th day the removal efficiency was increased to about $50 \%$. Slow sand filters were operated continuously and slow and stable increase in the removal efficiency was observed till 27th day of experimentation. On 17 th day, the removal efficiency was about $56 \%$ and on day 28 , it was increased to about $59.3 \%$ means $59 \%$ hexavalent chromium was removed till 27 th day. After that, the removal efficiency was increasing stably and slowly. The maximum removal efficiency was observed on day 31 i.e. about $61 \%$ and at last day of experiment that was 37 th day the removal efficiency was about $60 \%$. In present research an iron oxidizing bacteria was used as hexavalent chromium reducer. The basic mechanism behind this is that these organisms obtain energy for their growth from oxidation of different inorganic sulphur compounds (Donati et al., 2003). Oxidation of such compounds results in production of reducing agents that are present on colloidal sulphur and result in reduction of hexavalent chromium $\left(\mathrm{Cr}^{6+}\right)$ to trivalent chromium $\left(\mathrm{Cr}^{3+}\right)$ that is more stable and non-toxic form of chromium than $\mathrm{Cr}^{6+}$ (Quilntana et al., 2001). Reduction ability of colloidal sulphur increases in case of low pH (Quilntana et al., 2001). So a clear decrease in the concentration of hexavalent chromium was observed in present study. A study on speciation and removal of chromium from aqueous solution by white, yellow and red sand revealed that at $\mathrm{pH}<4$, the adsorption of hexavalent chromium $\left(\mathrm{Cr}^{6+}\right)$ was very low i.e. $10 \%$ while $\mathrm{Cr}$ (III) was totally adsorbed. In this study removal of trivalent chromium $\left(\mathrm{Cr}^{3+}\right)$ and hexavalent chromium $\left(\mathrm{Cr}^{6+}\right)$ from aqueous solution by different types of sand as low-cost abundant absorbent was investigated (Khamis et al., 2009). In another study, the adsorption ability of hexavalent chromium on dolochar was studied which is a less expensive naturally occurring adsorbent. Dolochar was found to be an efficient adsorbent for chromium removal from synthetic waste water. Batch adsorption experiment have been conducted by varying adsorbent dose, adsorbate concentration, $\mathrm{pH}$, particle size, time on removal of chromium of these metal ions (Panda 
et al., 2011). It was found that more than $94 \%$ of the removal was achieved under optimal condition while in the present research $60 \%$ removal was achieved where normal sand was used as adsorbent and bacterial culture was also used to see the combine effects on the removal of hexavalent chromium from syhthetic wastewater. In another study researchers used another strategy for the removal of hexavalent chromium from aqueous solution in which they used Thiobacillus thioparus for the indirect reduction of hexavalent chromium. Their results in the Fig. 6 showed the values for reduction of hexavalent chromium very close to $100 \%$ at different $\mathrm{pH}$ (Donati et al., 2003).

\subsection{Comparison of Removal efficiency}

In this research, iron and hexavalent chromium was removed through slow sand filtration technique. The figure showing comparison between removal efficiency of iron and hexavalent chromium $\left(\mathrm{Cr}^{6+}\right)$ via slow sand filters (SSF). At start of experiment a very low increase in the removal efficiency of $\mathrm{Fe}^{2+}$ and $\mathrm{Cr}^{6+}$ was observed. On 5th day, it was observed that the removal efficiency of ferrous iron was $5 \%$ while that of the chromium was $27.2 \%$. On 30th day it was observed that removal efficiency of hexavalent chromium was $59.6 \%$ as compared to ferrous iron whose removal efficiency was $51.3 \%$. After that slow and stable increase in removal efficiency was observed. On last day that was 37th day it was seen that the removal efficiency of hexavalent chromium $\left(\mathrm{Cr}^{6+}\right)$ was $60.2 \%$ while the removal efficiency of ferrous iron $\left(\mathrm{Fe}^{2+}\right)$ was $52.3 \%$. The Fig. 7 overall suggests that the designed slow sand filters were more efficient in the removal of hexavalent chromium as compared to iron.

\subsection{Slow sand filter 4 (Simultaneous treatment)}

This setup was run for almost 6 days at room temperature $(25 \pm 5)$ in which simultaneous removal of iron and hexavalent chromium was observed. Bacterial count that was inoculated in the filter was approximately $5.7 \cdot 10^{9} \mathrm{CFU} / \mathrm{mL}$ and iron and chromium wastewaters were added to the same filter as influent while effluent collected was the mixture of both solutions. The figure showing the removal efficiency of both ferrous iron and hexavalent chromium when they were treated within the same SSF. It was observed that on first day removal efficiency of hexavalent chromium $\left(\mathrm{Cr}^{6+}\right)$ was $64.13 \%$ whereas removal efficiency of ferrous iron was $43.47 \%$. As the experimentation continued, it was observed that removal efficiency was increasing stably. At the end of the experiment i.e. 6th day, removal efficiency of hexavalent chromium was about $93 \%$ while the removal efficiency of ferrous iron was $68.4 \%$. Hexavalent chromium $\left(\mathrm{Cr}^{6+}\right)$ can be reduced abiotically by aqueous $\mathrm{Fe}^{2+}$ (Bishop et al., 2014). So this property of ferrous iron can be reason for increased removal efficiency of hexavalent chromium in the present study. A study was conducted on synergistic effect of iron (III) minerals and dissimilatory metal reducing bacteria on the reduction of hexavalent chromium revealed that Iron (III) minerals and anthraquinone-2,6disulfonate (AQDS) synergistically enhance bio-reduction of hexavalent chromium (Meng et al., 2018). Oxidation of such compounds results in the production of reducing agents that are present on colloidal sulphur and causes the reduction of hexavalent chromium $\left(\mathrm{Cr}^{6+}\right)$ to trivalent chromium $\left(\mathrm{Cr}^{3+}\right)$ that is more stable and non-toxic form of chromium than $\mathrm{Cr}^{6+}$ (Quilntana et al., 2001). Reduction ability of colloidal sulphur increases in case of low pH (Quilntana et al., 2001) as shown in the Fig. 8. 


\subsection{Field Application}

Water sample was collected from Water filtration plant, Abbottabad that was tested for different parameters and then was compared to the results of treated water of currently studied slow sand filter. Different parameters like $\mathrm{pH}$, turbidity, hardness were checked before and after treatment. It was observed that $\mathrm{pH}$ of the water before and after passing through slow sand filter (SSF) remained same. A very slight change in turbidity of tested water was observed i.e. before treatment turbidity of water was $1.27 \pm 0.48$ and after treatment it was $0.96 \pm 0.05$. It was also observed that hardness of water was also being reduced very slightly after treatment of water through SSF Regarding microbiological analysis like total plate count (TPC) was checked. A decrease in Total plate count (TPC) was observed on nutrient agar i.e. $22 \pm 4.12 \mathrm{CFU}$ in average (after treatment) as compared to $40.5 \pm 6.36$ (before treatment). As shown in the Table 2

Table 2

Analysis of water before and after treatment through lab scale SSF

\begin{tabular}{|llll|}
\hline S. No. & Parameters & Before treatment & After treatment \\
\hline 1 & $\mathrm{pH}$ & $8.6 \pm 0$ & $8.6 \pm 0$ \\
2 & Turbidity, NTU & $1.27 \pm 0.48$ & $0.96 \pm 0.05$ \\
3 & TPC (cfu/ml) & $40.5 \pm 6.36$ & $22 \pm 4.12$ \\
4 & Hardness, (mg/L) & $169.33 \pm 16.772$ & $120 \pm 20$ \\
\hline
\end{tabular}

Water samples collected from water filtration plant were also checked for different parameters as shown in the table below. It was observed that there was a very slight change in the $\mathrm{pH}$, temperature, total dissolved solids, and electrical conductivity table (3) However, it was observed that turbidity was decreased to permissible limit. Similarly, value of hardness reduced to half till the end of the process or collection of effluent. According to the test report provided by the higher authority of the filtration plant, no E.coli colony was found in the water. 
Table 3

Analysis of effluent and influent collected from Water filtration plant Abbottabad

\begin{tabular}{|llll|}
\hline S.No & Parameters & Raw water & Slow sand filtration effluent \\
\hline 1 & $\mathrm{pH}$ & $8.12 \pm 0.05$ & $7.94 \pm 0.005$ \\
\hline 2 & Temperature $\left({ }^{\circ} \mathrm{C}\right)$ & $29 \pm 0.1$ & $29.9 \pm 0.15$ \\
\hline 3 & Turbidity $(\mathrm{NTU})$ & $6.34 \pm 0.2$ & $0.29 \pm 0.2$ \\
\hline 4 & Hardness $(\mathrm{mg} / \mathrm{L})$ & $32 \pm 1$ & $16 \pm 0$ \\
\hline 5 & TDS $(\mathrm{ppm})$ & $60.33 \pm 2.08$ & $61.3 \pm 1.5$ \\
\hline 6 & Electrical conductivity $\left(\mu^{\mathrm{s}}\right)$ & $125.66 \pm 0.57$ & $124 \pm 1$ \\
\hline
\end{tabular}

Iron and hexavalent chromium was also checked in the treated water after slow sand filtration. It was observed that total iron in the influent was about $22 \mathrm{mg} / \mathrm{L}$ while in effluent it was $8.13 \mathrm{mg} / \mathrm{L}$ approximately and slow sand filters were able to reduce iron upto $37 \%$ approximately. But it was observed that the concentration of ferrous iron in the effluent (treated water) was more than the concentration in the influent. Concentration of hexavalent chromium $\left(\mathrm{Cr}^{6+}\right)$ was also analysed in the effluents and influents. It was seen that concentration of hexavalent chromium was reduced from $40 \mathrm{mg} / \mathrm{L}$ to $28 \mathrm{mg} / \mathrm{L}$ approximately.

Schemutzdecke layer from the slow sand filter was also collected to check the presence or absence of iron oxidizing Acidothiobacillus ferrooxidans bacteria. It was observed that after 7 days of incubation, only single colony of iron oxidizing bacteria was grown on the media. In this research instead of native schumutzdecke layer, the synthetic layer was applied that was composed of isolated culture of Acidothiobacillus ferrooxidans i.e. the iron oxidizing bacteria. So the bacterial strains were also performing their functions and oxidizing the ferrous iron into ferric iron, hence reducing the concentration of ferrous iron in the effluent. In a study it was revealed that these organisms have ability to drive energy for their growth via oxidation of ferrous $\left(\mathrm{Fe}^{2+}\right)$ iron by oxygen $\left(\mathrm{O}_{2}\right)$ resulting in the formation of ferric iron $\left(\mathrm{Fe}^{3+}\right)$ and water $\left(\mathrm{H}_{2} \mathrm{O}\right)$ and fixation of $\mathrm{CO}_{2}$ from environment (Campodonico et al., 2016).

\section{Conclusion}

In this research, slow sand filters were designed that were inoculated with iron oxidizing bacteria Acidothiobacillus ferrooxidans and were allowed to remove ferrous iron and hexavalent chromium from water samples via oxidation of ferrous iron to ferric iron and reduction of hexavalent chromium to trivalent chromium, $\mathrm{Cr}^{3+}$. At the end of the experimentation the removal efficiency for ferrous iron was about $52.3 \%$ means decreased the concentration from 200 to $106 \mathrm{mg} / \mathrm{L}$. The removal efficiency of hexavalent chromium was about $61 \%$ (decreased from 500 to $198.6 \mathrm{mg} / \mathrm{L}$ ). So, in conclusion, the 
designed slow sand filters were able to reduce the concentration of hexavalent chromium more efficiently than ferrous iron. And it was clearly observed that slow sand filters can effectively remove ferrous iron and hexavalent chromium from water if they are inoculated with respective bacteria.

\section{Declarations}

Ethics approval and consent to participate: This is non-human subject research, and waived the need for informed consent.

Declaration of interests :The authors declare that they have no known competing financial interests or personal relationships that could have appeared to influence the work reported in this paper. Funding: No funding

Consent to Participate/Publish: Authors contributed to the study conception and design. The authors read and approved the final manuscript.

Authors Contributions: "Not applicable"

Availability of data and materials: The datasets used and/or analyzed during the current study are available from the corresponding author on reasonable request.

\section{References}

ALIMOHAMMADI, V., SEDIGHI, M. \& JABBARI, E. 2017. Experimental study on efficient removal of total iron from wastewater using magnetic-modified multiwalled carbon nanotubes. Ecological Engineering, $102,90-97$.

BISsHOP, M. E., GLASSER, P., DONG, H., AREY, B. \& KOVARIK, L. 2014. Reduction and immobilization of hexavalent chromium by microbially reduced Fe-bearing clay minerals. Geochimica et Cosmochimica Acta, $133,186-203$.

CALVO-BADO, L. A., PETTITT, T. R., PARSONS, N., PETCH, G. M., MORGAN, J. A. W. \& WHIPPS, J. M. 2003. Spatial and temporal analysis of the microbial community in slow sand filters used for treating horticultural irrigation water. Applied and environmental microbiology, 69, 2116-2125.

CAMPODONICO, M. A., VAISMAN, D., CASTRO, J. F., RAZMILIC, V., MERCADO, F., ANDREWS, B. A., FEIST, A. M. \& ASENJO, J. A. 2016. Acidithiobacillus ferrooxidans's comprehensive model driven analysis of the electron transfer metabolism and synthetic strain design for biomining applications. Metabolic Engineering Communications, 3, 84-96

CHATURVEDI, S. \& DAVE, P. N. 2012. Removal of iron for safe drinking water. Desalination, 303, 1-11. 
CHOWDHURY, S., MAZUMDER, M. J., AL-ATTAS, O. \& HUSAIN, T. 2016. Heavy metals in drinking water: occurrences, implications, and future needs in developing countries. Science of the Total Environment, $569,476-488$.

DIELS, L., SPAANS, P. H., VAN ROY, S., HOOYBERGHS, L., RYNGAERT, A., WOUTERS, H., WALTER, E., WINTERS, J., MACASKIE, L., FINLAY, J., PERNFUSS, B., WOEBKING, H., PÜMPEL, T. \& TSEZOS, M. $2003 b$. Heavy metals removal by sand filters inoculated with metal sorbing and precipitating bacteria. Hydrometallurgy, 71, 235-241.

DONATI, E., OLIVER, C. \& CURUTCHET, G. 2003. Reduction of chromium (VI) by the indirect action of Thiobacillus thioparus. Brazilian Journal of Chemical Engineering, 20, 69-73.

DOPSON, M. \& LINDSTROM, E. B. 1999. Potential role of thiobacillus caldus in arsenopyrite bioleaching. Appl Environ Microbiol, 65, 36-40.

Fatima, Tehreem, Abrar Hussain Mian, Zanib Khan, Arshad Mehmood Khan, Faheem Anwar, Ayesha Tariq, and Momina Sardar. "Citrus sinensis a potential solution against superbugs." APPLIED NANOSCIENCE (2020).

GOWD, S. S. \& GOVIL, P. K. 2008. Distribution of heavy metals in surface water of Ranipet industrial area in Tamil Nadu, India. Environmental Monitoring and Assessment, 136, 197-207.

GOWD, S. S. \& GOVIL, P. K. 2008. Distribution of heavy metals in surface water of Ranipet industrial area in Tamil Nadu, India. Environmental Monitoring and Assessment, 136, 197-207.

GUPTA, V. \& RASTOGI, A. 2009. Biosorption of hexavalent chromium by raw and acid-treated green alga Oedogonium hatei from aqueous solutions. Journal of Hazardous Materials, 163, 396-402.

HAIG, S., COLLINS, G., DAVIES, R., DOREA, C. \& QUINCE, C. 2011. Biological aspects of slow sand filtration: past, present and future. Water Science and Technology: Water Supply, 11, 468-472.

HEADLAM, H. A. \& LAY, P. A. 2016. Spectroscopic characterization of genotoxic chromium (V) peptide complexes: Oxidation of Chromium (III) triglycine, tetraglycine and pentaglycine complexes. Journal of inorganic biochemistry, 162, 227-237.

Jusoh, H., Sapari, N., \& Azie, R. R. (2011). Removal of iron from groundwater by sulfide precipitation. World Academy of Science, Engineering and Technology, (60), 652-658.

KHAMIS, M., JUMEAN, F. \& ABDO, N. 2009. Speciation and removal of chromium from aqueous solution by white, yellow and red UAE sand. Journal of hazardous materials, 169, 948-952. 
KHATRI, N., TYAGI, S. \& RAWTANI, D. 2016. Assessment of drinking water quality and its health effects in rural areas of Harij Taluka, Patan district of Northern Gujarat. Environmental Claims Journal, 28, 223-246.

KRISHNA, A. K., SATYANARAYANAN, M. \& GOVIL, P. K. 2009. Assessment of heavy metal pollution in water using multivariate statistical techniques in an industrial area: A case study from Patancheru, Medak District, Andhra Pradesh, India. Journal of Hazardous Materials, 167, 366-373.

LEE, E. \& OKI, L. R. 2013. Slow sand filters effectively reduce Phytophthora after a pathogen switch from Fusarium and a simulated pump failure. Water research, 47, 5121-5129.

MENG, Y., ZHAO, Z., BURGOS, W. D., LI, Y., ZHANG, B., WANG, Y., LIU, W., SUN, L., LIN, L. \& LUAN, F. 2018. Iron (III) minerals and anthraquinone-2, 6- disulfonate (AQDS) synergistically enhance bioreduction of hexavalent chromium by Shewanella oneidensis MR-1. Science of the total environment, 640, 591-598.

Mian, A.H., Fatima, T., Qayyum, S. et al. A study of bacterial profile and antibiotic susceptibility pattern found in drinking water at district Mansehra, Pakistan. Appl Nanosci (2020).

https://doi.org/10.1007/s13204-020-01411-0

NSENGIYUMVA, D. 1997. Field evaluation of three systems for filtering polluted river water for use in subsurface irrigation.

PANDA, L., DAS, B., RAO, D. \& MISHRA, B. 2011. Application of dolochar in the removal of cadmium and hexavalent chromium ions from aqueous solutions. Journal of hazardous materials, 192, 822-831.

PARAMASIVAM, R., MHAISALKAR, V. \& BERTHOUEX, P. M. 1981. Slow sand filter design and construction in developing countries. Journal-American Water Works Association, 73, 178-185.

PARANYCHIANAKIS, N. V., ANGELAKIS, A. N., LEVERENZ, H. \& TCHOBANOGLOUS, G. 2006. Treatment of wastewater with slow rate systems: a review of treatment processes and plant functions. Critical reviews in environmental science and technology, 36, 187-259.

PRADHAN, D., SUKLA, L. B., SAWYER, M. \& RAHMAN, P. K. 2017. Recent bioreduction of hexavalent chromium in wastewater treatment: A review. Journal of Industrial and Engineering Chemistry, 55, 1-20.

Qayyum, S., Basharat, S., Mian, A. H., Qayum, S., Ali, M., Changsheng, P., ... \& Sultan, F. (2020). Isolation, identification and antibacterial study of pigmented bacteria. Appl Nanosci https://doi. org/10.1007/s1320, 4-020.

Qayyum, S., Nasir, A., Mian, A. H., Rehman, S., Qayum, S., Siddiqui, M. F., \& Kalsoom, U. (2020). Extraction of peroxidase enzyme from different vegetables for biodetoxification of vat dyes. Applied Nanoscience, 19.

QUIINTANA, M., CURUTCHET, G. \& DONATI, E. 2001. Factors affecting chromium (VI) reduction by Thiobacillus ferrooxidans. Biochemical Engineering Journal, 9, 11-15. 
SILVERMAN, M. P. \& LUNDGREN, D. G. 1959. Studies on the chemoautotrophic iron bacterium Ferrobacillus ferrooxidans: I. An improved medium and a harvesting procedure for securing high cell yields. Journal of bacteriology, 77, 642.

STEWART-WADE, S. M. 2011. Plant pathogens in recycled irrigation water in commercial plant nurseries and greenhouses: their detection and management. Irrigation Science, 29, 267-297.

TEKERLEKOPOULOU, A. G., PAVLOU, S. \& VAYENAS, D. V. 2013. Removal of ammonium, iron and manganese from potable water in biofiltration units: a review. Journal of Chemical Technology and Biotechnology, 88, 751-773.

ZEVI, Y., DEWITA, S., AGHASA, A. \& DWINANDHA, D. 2018. Removal of Iron and Manganese from Natural Groundwater by Continuous Reactor Using Activated and Natural Mordenite Mineral Adsorption. IOP Conference Series: Earth and Environmental Science, 111, 012016.

\section{Figures}

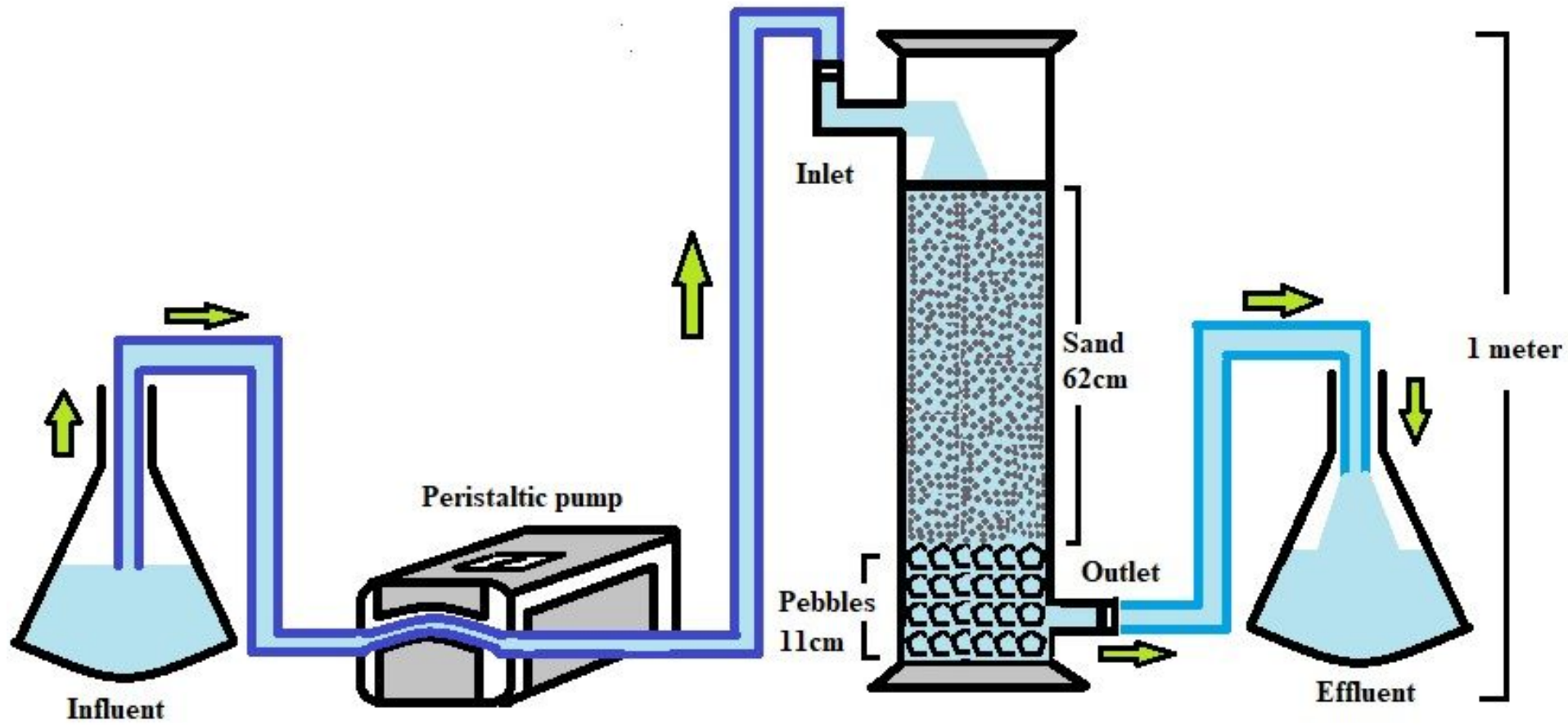

SLOW SAND FILTER DESIGN

Figure 1

Slow sand filtration setup design 
SSF as a control

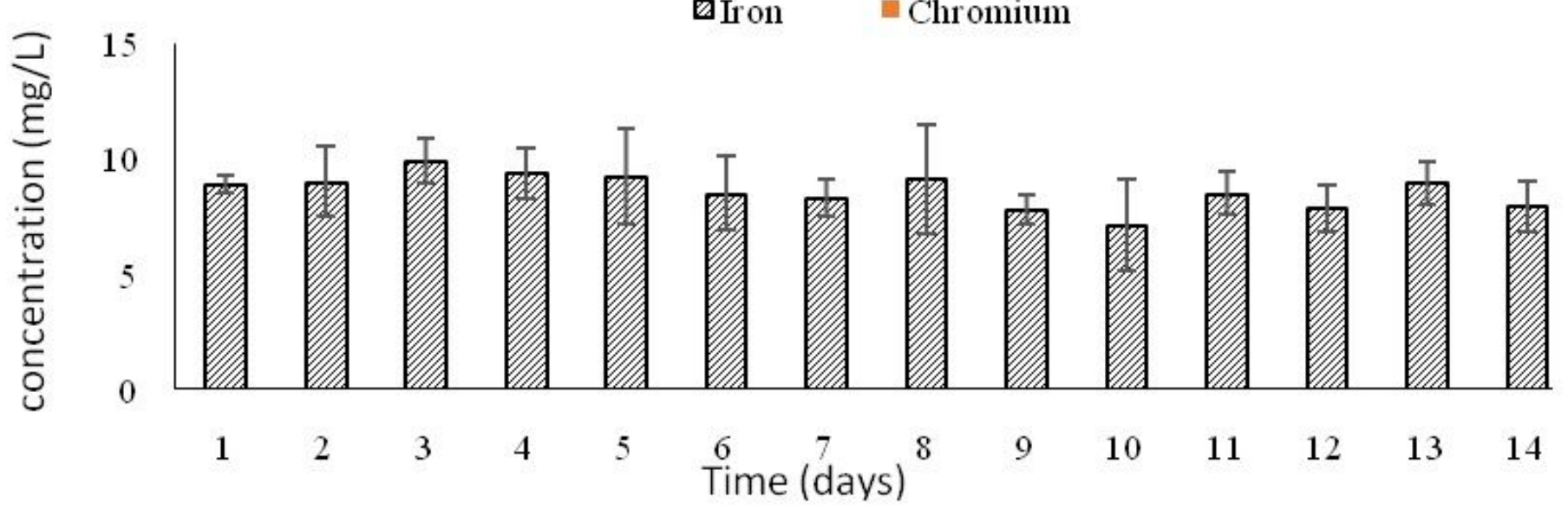

Figure 2

Concentration of Ferrous iron and Hexavalent chromium in the effluents of control setup

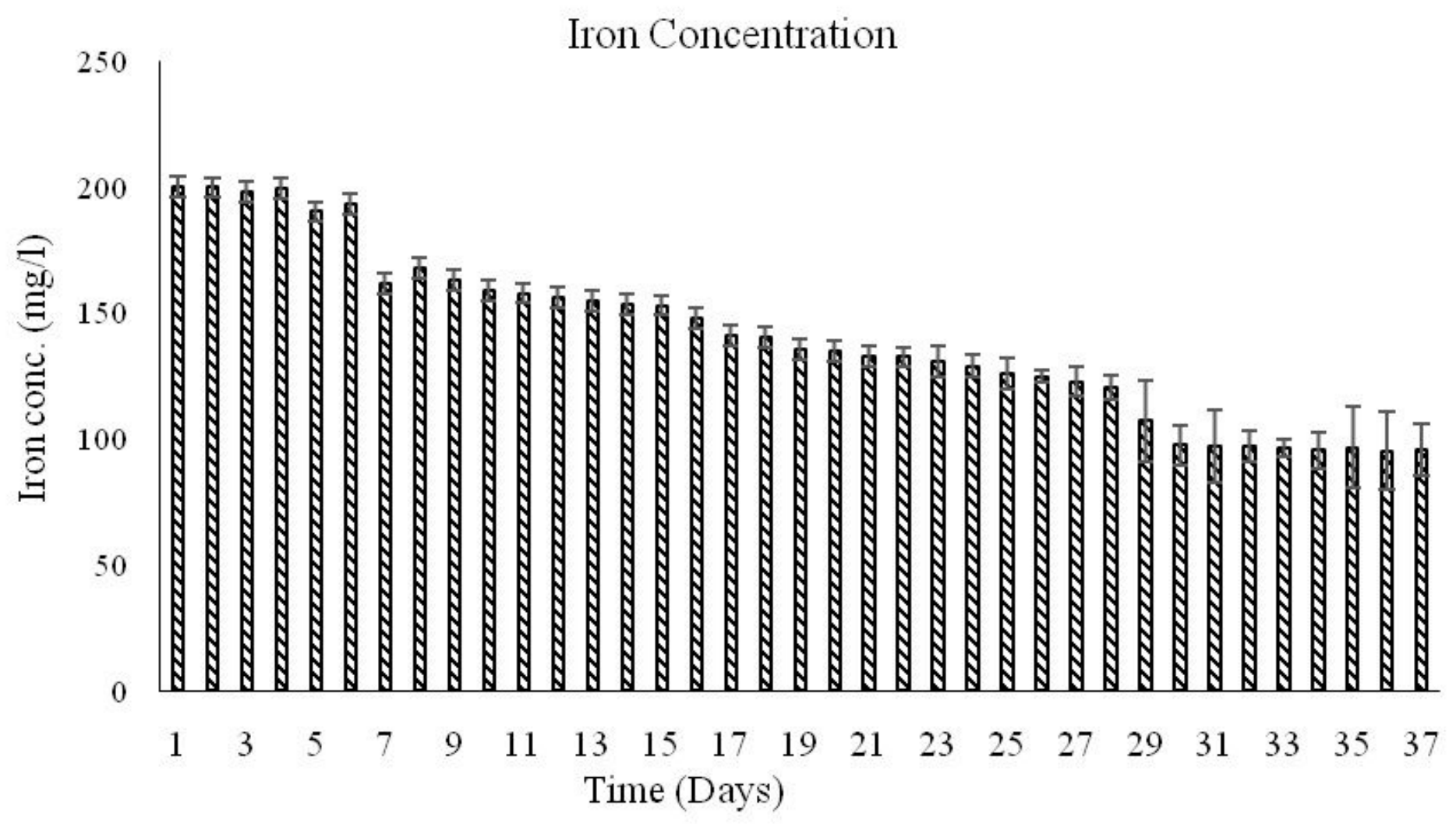

Figure 3

Concentration of ferrous iron in the effluents after treatment 


\section{$\mathrm{Fe}^{2+}$ Removal efficiency}

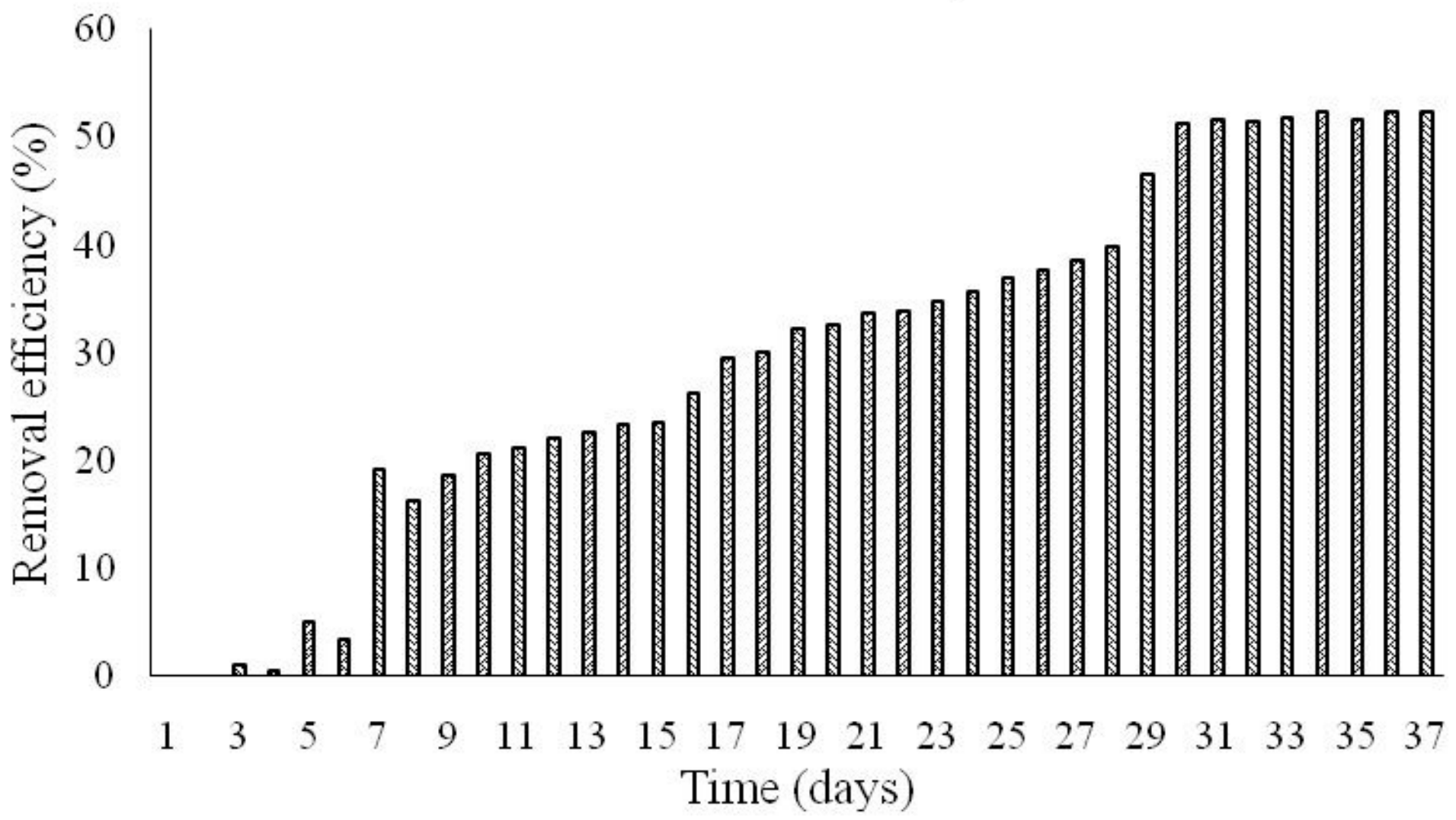

Figure 4

Removal efficiency of ferrous ( $\mathrm{Fe} 2+)$ iron 


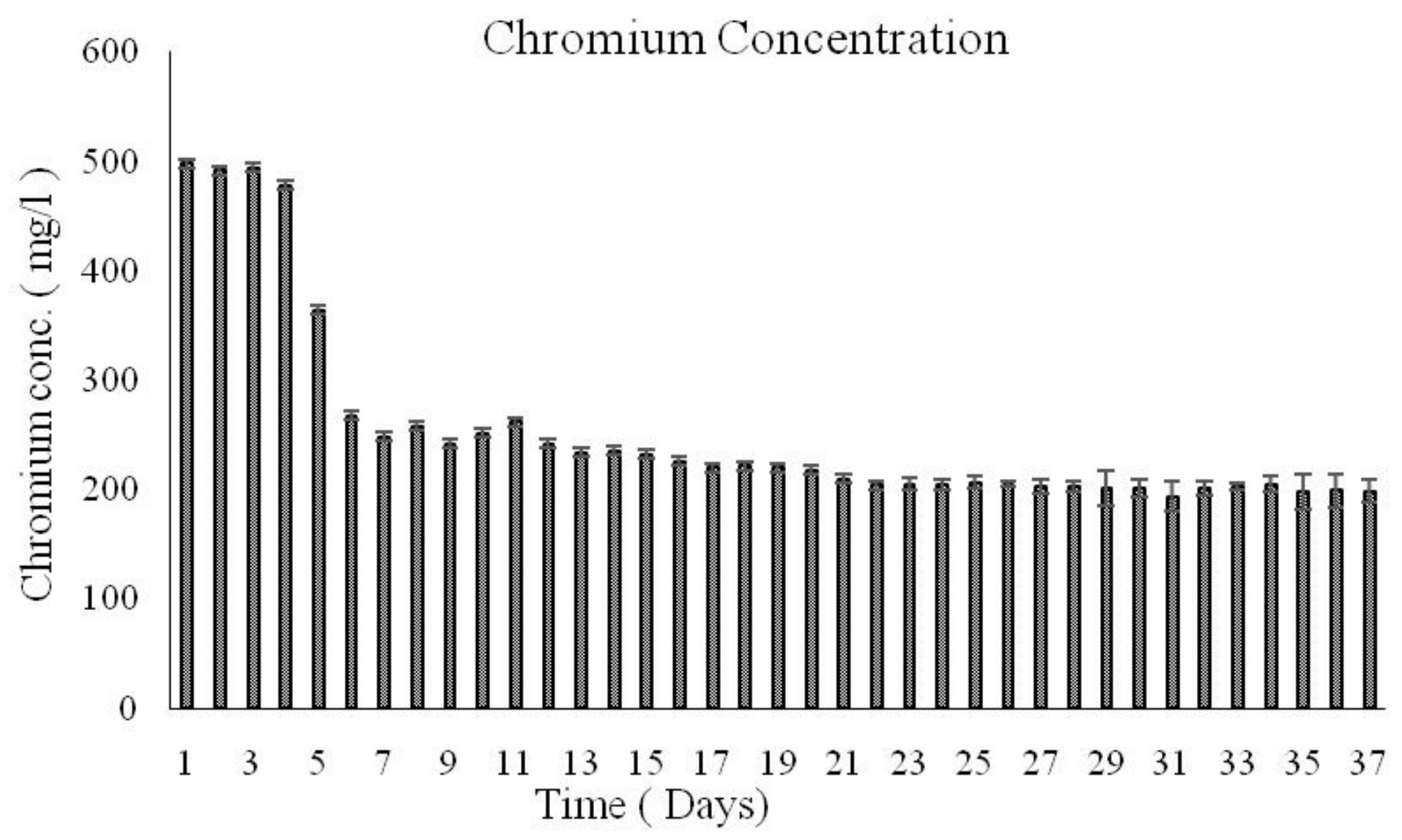

Figure 5

Concentration of $\mathrm{Cr} 6+$ in the effluents after treatment 
Removal efficiency of $\mathrm{Cr}^{6+}$

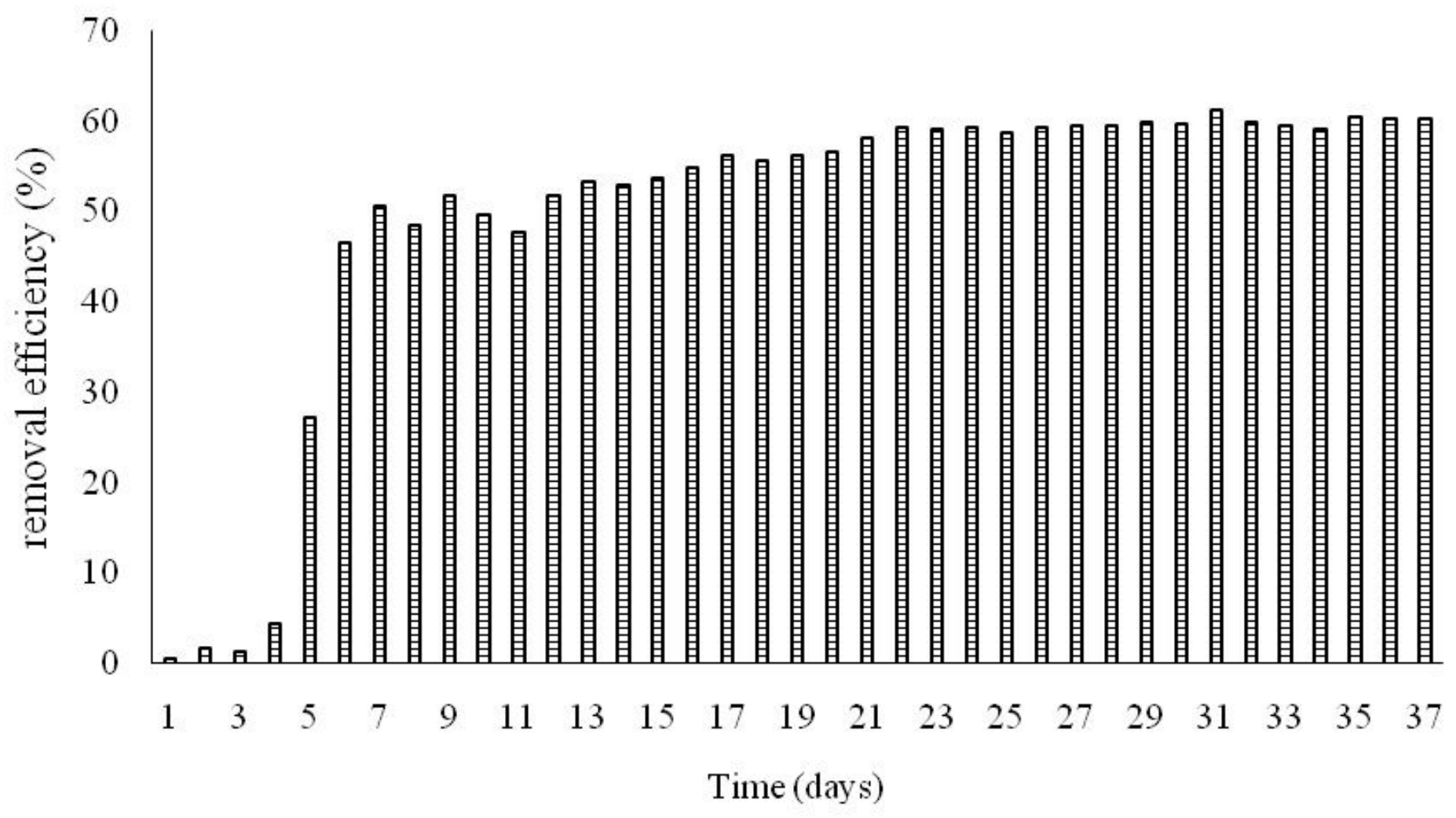

Figure 6

Removal efficiency of hexavalent chromium (Cr6+)(Qayyum et al., 2020) 
Comparsion of Removal Efficiency

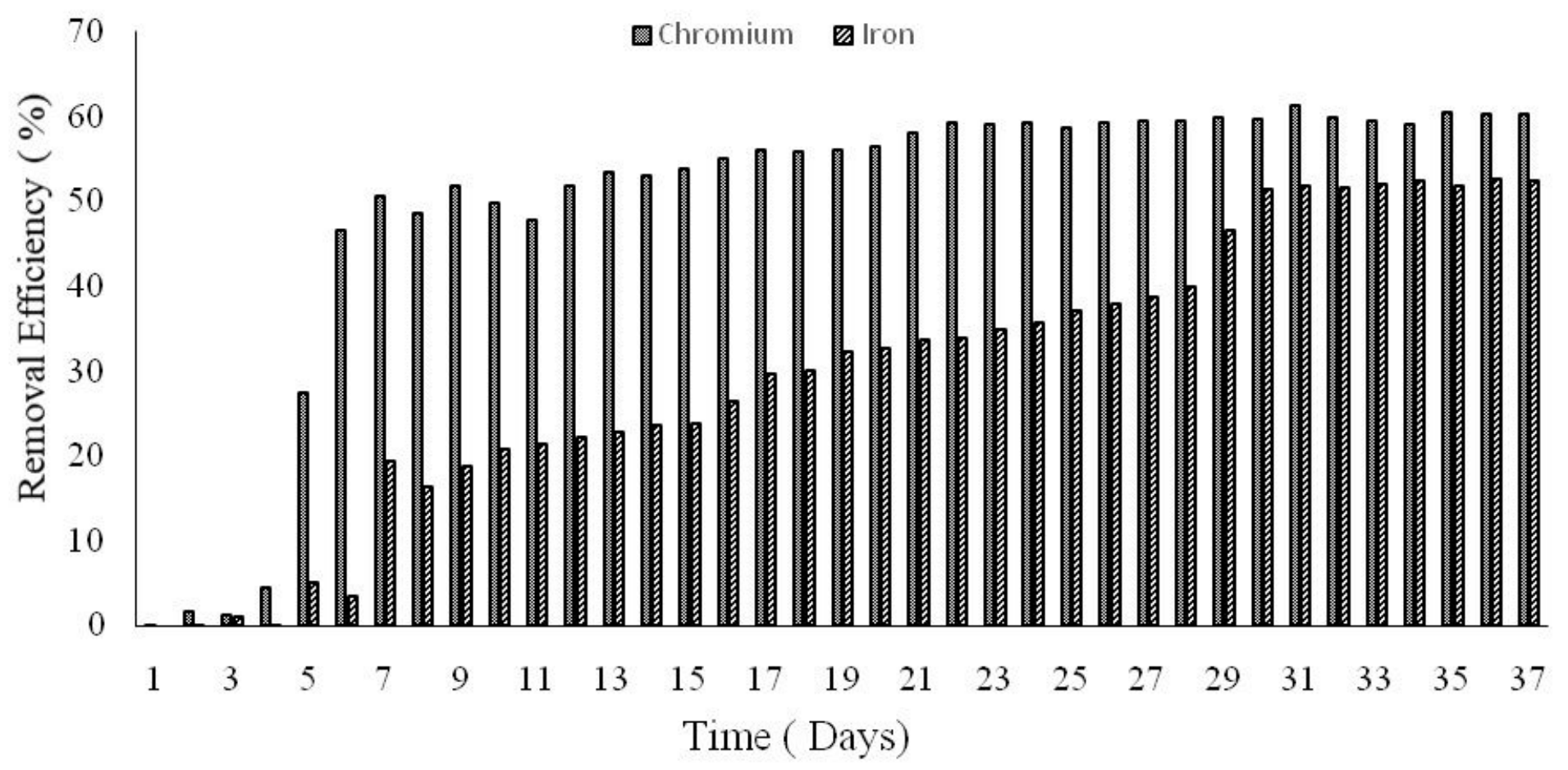

Figure 7

Comparison of removal efficiency of Fe2+ and Cr6+ (Qayyum et al., 2020)

Simultaneous removal efficiency

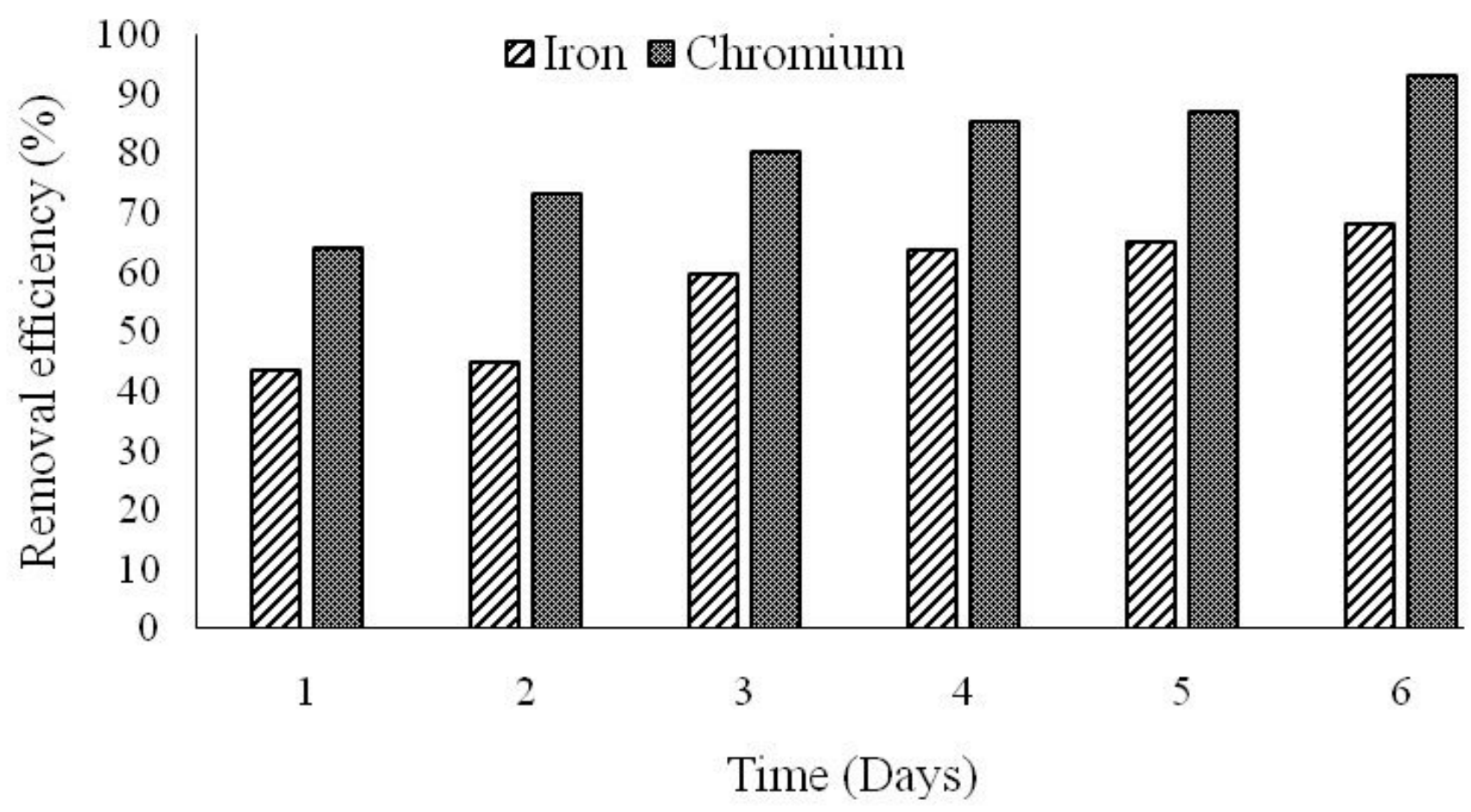


Figure 8

Slow sand filter 4 (Simultaneous treatment) 